\title{
MEMBANGUN KARAKTER MANDIRI MELALUI PEMBELAJARAN BIOLOGI SELAMA MASA PANDEMI COVID-19
}

\author{
Neni Suherni \\ Madrasah Aliyah Negeri 1 Kuningan \\ Jln. Mayasih No. 881 Cigugur Kuningan \\ E-mail : nenisuherni88@gmail.com
}

\begin{abstract}
Abstrak
Penelitian ini merupakan penelitian tindakan kelas (PTK) yang dilaksanakan selama masa pandemi Covid-19, dimulai dari mulai Juli 2020 sampai bulan September 2020, dengan latar belakang adanya kekhawatiran tentang kemandirian belajar siswa selama masa pandemi Covid-19 yang menggunakan sistem belajar daring/non tatap muka. Subjek penelitian adalah siswa kelas XII IPA 2 Madrasah Aliyah Negeri 1 Kuningan tahun pelajaran 2020/2021, yang terdiri 33 siswa.Hasil penelitian melalui pembelajaran Biologi menunjukan masih rendahnya kemandirian belajar siswa sebesar $35,7 \%$ siswa yang selalu berusaha untuk mengerjakan sendiri tugas-tugas dari sekolah selama masa pandemi Covid-19. Serta sebesar 39,3\% siswa yang sering berusaha untuk mengerjakan tugas tepat waktu selama masa pandemi Covid-19. Berdasarkan hasil penelitian, menunjukan rendahnya tingkat kemandirian belajar siswa selama masa pandemi Covid-19. Peran guru, orang tua serta sekolah untuk member motivasi kepada peserta didik..
\end{abstract}

Kata Kunci : Biologi - Kemandirian - Pandemi Covid-19.

Abstract

This research is class action research which is carried out in Covid-19 Pandemi period, it starts from July 2020 till September 2020. The subject of this research is 33 students of class XII Science 2 in MAN 1 Kuningan in 2020/2021 academic year.

The results of this though biology learning express the low of students learning independence, it shows $35.7 \%$ of students who try to accompolish their assignments independently along this pandemi period. And its only $39.3 \%$ of population who carry out theit duties on time in this pandemi period.

Based on the results of research, it shows the low of students learning independently level along this pandemic period. And it need teachers parent and schools role to motivate them.

Keywords:Biology-Covid 19 Pandemi- Independency

\section{PENDAHULUAN}

Pendidikan merupakan suatu sistem yang sangat penting bagi masyarakat suatu bangsa, dan akan semakin penting bila semua itu teraktualisasikan dalam kehidupan sosial masyarakat,maka dari itu, pihak-pihak yang berada di dalamnya mulai dari peserta didik, pendidik maupun organisasi pendidikan harus tahu dan paham apa yang harus dan perlu dilakukan atau dikerjakan dalam mengembangkan kemampuan, mengembangkan kualitas serta mengaktualisasikannya dalam kehidupan sehari-hari maupun dalam memandang masa depan(Ali M Aisyah, 2013).

Proses pendidikan akan jauh lebih baik dan sempurna jika setiap peserta didik sadar akan tujuan pendidikan yaitu untuk mendapatkan ilmu serta keberania (kemandirian) untuk mengambil sikap maupun keputusan dalam menjalani kehidupan di masa depan (Ali, 2013).

Pengertian Kemandirian secara psikologis dan mentalis yaitu keadaan seseorang yang dalam kehidupannya mampu memutuskan dan mengerjakan 
sesuatu tanpa bantuan dari orang lain. Kemampuan demikian hanya mungkin dimiliki jika seseorang berkemampuan memikirkan dengan seksama tentang sesuatu yang dikerjakannya atau diputuskannya, baik dalam segi-segi manfaat dialaminya (Hasan Basri,2000: 53). Setiap kegiatan yang dilakukan oleh seseorang agar berhasil sesuai keinginan dirinya maka diperlukan adanya Kemandirian yang kuat

Anton Sukarno

menyebutkan siswa atau peserta didk yang memilikiciri-

ciri KemandirianBelajarditandai dengan hal-hal sebagai berikut:

1) Siswa merencanakan dan memilih kegiatan Belajar sendiri

2) Siswa berinisiatif dan memacu diri untuk Belajar secara terus menerus

3) Siswa dituntut bertanggung jawab dalam Belajar

4) Siswa Belajar secara kritis, logis, dan penuh keterbukaan

5) Siswa Belajar dengan penuh percaya diri

Proses pembelajaran dimasa pandemi covid-19dimana pembelajaran dilakukan di rumah secara daring, menuntut siswa untuk bisa belajar mandiri, bisa mengatur waktu, untuk mengerjakn tugas-tugas yang diberikan oleh guru di sekolah, tanpa bantuan orang tua ataupun tidak, siswa harus mampu belajar mandiri.

Kemandirian merupakan salah satu aspek kepribadian yang sangat penting bagi individu. Seseorang dalam menjalani kehidupan ini tidak pernah lepas dari cobaan dan tantangan. Individu yang memilliki kemandirian tinggi relative mampu menghadapi segala permasalahan karena individu yang mandiri tidak tergantung pada orang lain, selalu berusaha menghadapi dan memecahkan masalah yang ada. Menurut Antonius (2000:145) yaitu:

Seseorang yang mandiri adalah suatu suasana dimana seseorang mau dan mampu mewujudkan kehendak atau keinginan dirinya yang terllihat dalam tindakan atau perbuatan nyata guna menghasilkan sesuatu (barang atau jasa) demi pemenuhan kebutuhan hidupnya dan sesamanya".

Pada proses pembelajaran biologi dalam masa pandemi, metode pembelajaran yang bisa dilakukan sangat terbatas, karena semua peserta didik belajar di rumah masing-masing, kalaupun mau melaksanakan praktikum yang sederhana yang bisa dilakukan oleh siswa dengan alat dan bahan yang ada di rumah sehingga semua siswa bisa melaksanakan praktikum biologi tersebut.Melalui metode experimen, diharapkan siswa bisa belajar secara mandiri.

Kemandirian adalah kemampuan seseorang dalam mewujudkan kehendak atau keinginannya secara nyata dengan tidak bergantung pada orang lain. Dengan demikian yang dimaksud dengan kemandirian dalam penelitian ini adalah perilaku siswa dalam mewujudkan kehendak atau keinginannya secara nyata tidak bergantung pada orang lain, dalam hal ini adalah siswa tersebut mampu melakukan belajar sendiri, dapat menentukan cara belajar dengan baik dan mampu untuk melakukan aktifitas belajar secara mandiri(Suharno Anton, 1989).

Berdasarkan teori-teori di atas, penulis tertarik untuk melakukan penelitian dengan judul "Membangun Karakter Mandiri dalam pembelajaran Biologi selama masa pandemi Covid-19". Penelitian ini dilakukan terhadap siswa kelas XII IPA2 MAN I KUNINGAN.

\section{METODE PENELITIAN}

\section{A. Teknis Penelitian}

Jenis penelitian ini adalah Penelitian Tindakan Kelas.

\section{B. Subjek Penelitian}

Subjek penelitian adalah peserta didik kelas XII IPA2 di MAN I Kuningan yang berjumlah 33 peserta. Pengumpulan data penelitian menggunakan instrumen berupa kuesioner/angket yang disebarkan melalui Google Form. 


\section{Tempat Dan Waktu Penelitian}

Tempat Penelitian dilakukan di rumah masingp-masing peserta didik, dan waktu dilaksanakan penelitian adalah selama masa pandemi Covid-19 dimulai dari tgl 25 Juli sampai 12 September 2020.

\section{Desain Penelitian}

Analisis data penelitian dilakukan secara kuantitatif, yaitu dengan menghitung persentasi tingkat kemandirian belajar siswa. Dengan menggunakan instrument yang valid dan reliable dalam pengumpulan data, maka diharapakan hasil penelitian akan menjadi valid dan reliable.

\section{E. Hasil Dan Pembahasan}

Melalui pertanyaan di dalam angket berikut ini, didapatkan hasil berikut :

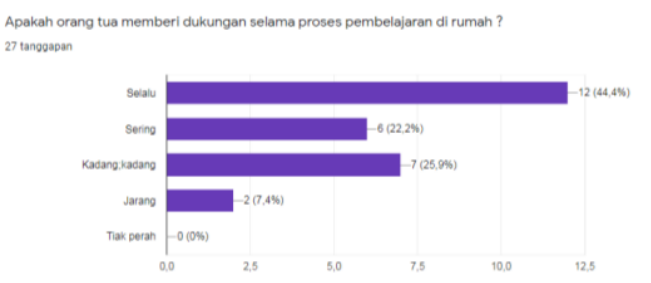

Tabel 4.1

Melalui pertanyaan dalam angket : Apakah orang tua memberi dukungan selama proses pembelajaran di rumah, didapatkan hasil respon dari 28 siswa seperti berikut :

sebanyak $44,4 \%$ selalu mendukung proses pembelajaran selama di rumah, dansebanyak $22,02 \%$ orang tua sering mendukung proses pembelajaran di rumah, dansejumlah $25,9 \%$ orang tua kadangkadang mendukungproses pembelajaran di rumah, dan sebanyak $7,4 \%$ orang tua jarang mendukung proses pembelajaran di rumah, dansebanyak $0 \%$ orang tua tidak pernah mendukung proses pembelajaran di rumah selama masa pandemi

Berdasarkan hasil penelitian, dapat diambil kesimpulan bahwa orang tua selalu mendukung proses pembelajaran siswa selama di rumah sebesar $44,4 \%$, artinya pihak orang tua sangat mendukung terhadap proses pembelajaran anaknya di rumah selama masa pandemi, tidak ada orang tua yang tidak mendukung proses pembelajaran anaknya di rumah selama masa pandemi.

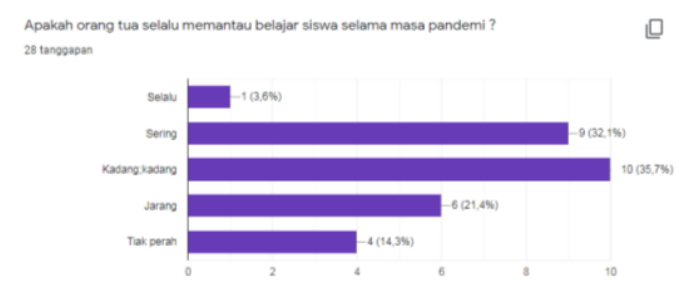

Tabel 4.2

Melalui pertanyaan apakah orang tua selalu memantau belajar siswa selama masa pandemi, didapatkan respons dari siswa, sebesar $3,6 \%$ orang tua selalu memantau belajar siswa, $32,1 \%$ orang tua sering memantau belajar siswa, $35,7 \%$ orang tua kadang-kadang memantau belajar siswa, dan $21,4 \%$ orang tua jarang memantau belajar siswa, dan $14,3 \%$ orang tua tidak pernah memantau belajar siswa selama masa pandemi.

Berdasarkan hasil penelitian mellalui angket,didapatkan hasil bahwa sebagian besar orang tua kadang-kadang memantau belajar anaknya selama masa pandemi, tetapi ada sebesar $14,3 \%$ orang tua yang tidak pernah memantau belajar anaknya selama masa pandemi.

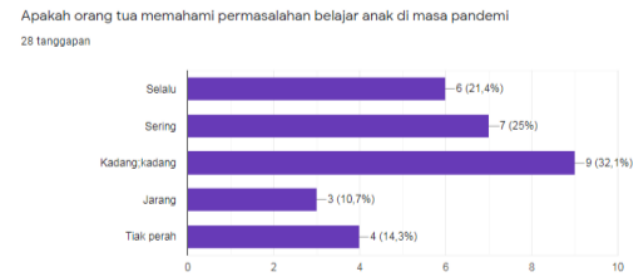

Tabel 4.3

Pertanyaan berikutnya, apakah orang tua memahami permasalahan belajar anak selama masa pandemi, didapatkan hasil respons jawaban dari siswa seperti berikut :

Sebesar $21,4 \%$ orang tua selalu memahami permasalahan belajar anak selama masa pandemi, sebesar $25 \%$ orang tua sering memahami permasalahan belajar anak selama masa pandemi, dan sebesar $32,1 \%$ orang tua kadang-kadang memahami permasalahan belajar anak masa pandemi, dan sebesar $10,7 \%$ orang tua jarang memahami permasalahan belajar 
anak di masa pandemi, serta sebesar 14,3\% orang tua tidak pernah memahami permasalahan belajar anak selama masa pandemi.

Menurut hasil respon siswa, didapatkan bahwa orang tua kadangkadang memahami permasalahan belajar anak selama masa pandemi.

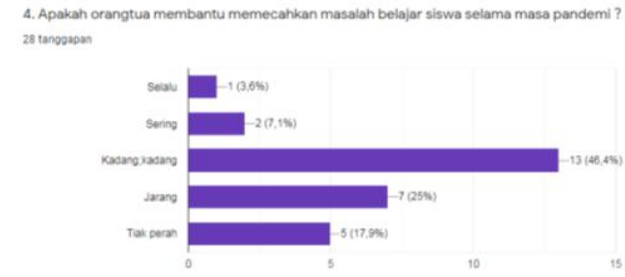

Tabel 4.4

Melalui pertanyaan apakah orang tua membantu memecahkan masalah belajar siswa selama masa pandemi ? Didapatkan hasil respon sejumlah 28 siswa, dengan data seperti berikut::

sebesar $3,6 \%$ orang tua selalu membantu memecahkan masalah belajar siswa selama masa pandemi,sebesar 7,1\% orang tua sering membantu memecahkan masalah belajar siswa selama masa pandemi, sebesar $46,4 \%$ orang tua kadangkadang membantu memecahkan masalah belajar siswa, serta sebesar $25 \%$ orang tua jarang membantu memecahkan masalah belajar siswa selama masa pandemi, dansebesar $17,9 \%$ orang tua tidak pernah membantu memecahkan masalah belajar siswa selama masa pandemi.

Menurut hasil penelitian, bahwa sebesar $46,4 \%$ orang tua kadang-kadang membantu memecahkan masalah belajar siswa selama masa pandemi, serta sebagian kecil sebesar 3,6\% orang tua yang selalu membantu memecahkan masalah belajar anaknya selama masa pandemi covid-19.

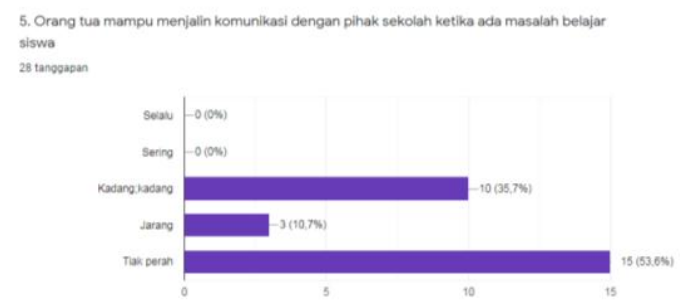

Tabel 4.5

Melalui pertanyaan : Orang tua mampu menjalin komunikasi dengan pihak sekolah ketika ada masalah belajar siswa , didapatkan data respon dari 28 siswa seperti berikut :

$0 \%$ orang tua selalu mampu menjalin komunikasi dengan pihak sekolah ketika ada masalah belajar siswa, dan $0 \%$ orang tua sering menjalin komunikasi dengan pihak sekolah ketika ada masalah belajar siswa, sebesar $35,7 \%$ orang tua kadangkadang menjalin komunikasi dengan pihak sekolah ketika ada masalah belajar siswa, serta sebesar $10,7 \%$ orang tua jarang menjalin komunikasi dengan pihak sekolah, serta sebesar $53,6 \%$ orang tua tidak pernah menjalin komunikasi dengan pihak sekolah ketika ada masalah belajar siswa selama masa pandemi.

Menurut hasil penelitian didapatkan sebesar $53,6 \%$ orang tua tidak pernah menjalin komunikasi dengan pihak sekolah ketika ada masalah belajar siswa selama masa pandemi, artinya siswa harus mampu memecahkan masalah belajar sendiri ketika masa pandemi covid-19.

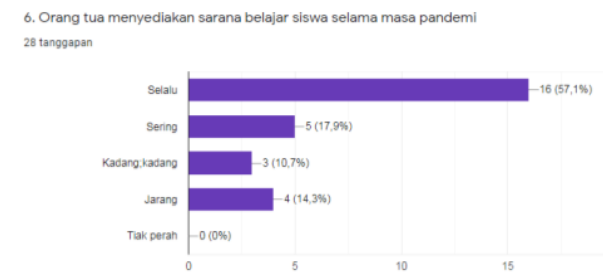

Tabel 4.6

Melalui pertanyaan : Orang tua menyediakan sarana belajar siswa selama masa pandemi, didapatkan data respon siswa seperti berikut :

sebesar $57,1 \%$ orang tua selalu menyediakan sarana belajar siswa selama masa pandemi, sebesar $17,9 \%$ orang tua sering menyediakan sarana belajar siswa, sebesar $10,7 \%$ orang tua kadang-kadang menyediakan sarana belajar siswa, serta sebesar $14,3 \%$ orang tua jarang menyediakan sarana belajar siswa, serta sebesar $0 \%$ orang tua tidak pernah 
menyediakan sarana belajar siswa selama masa pandemi.

Berdasarkan data hasil penelitian, dapat disimpulkan bahwa orang tua selalu menyediakan sarana belajar siswa selama masa pandemi, sebesar 57,1\%.

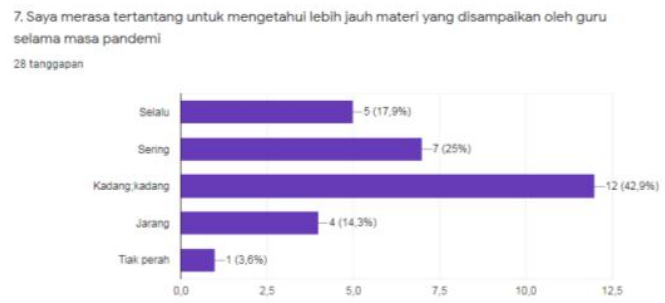

Tabel 4.7

Melalui pertanyaan : saya merasa tertantang untuk mengetahui lebih jauh materi yang disampaikan oleh guru selama masa pandemi, didapatkan hasil respon sejumlah 28 siswa, seperti berikut :

sebesar $17,9 \%$ siswa selalu merasa tertantang untuk mengethui lebih jauh materi yang diberikan guru, sebesar $25 \%$ siswa sering merasa tertantang untuk mengetahui lebih jauh materi yang diberikan guru, serta sebesar $42,9 \%$ siswa kadang-kadang merasa tertantang untukmengetahui lebih jauh materi, sebesar $14,3 \%$ siswa jarang tertantang untuk mengetahui materi lebih jauh, serta 3,6\% siswa tidak pernah tertantang untuk mengetahui materi lebih jauh materi yang diberikan guru selama masa pandemi.

Berdasarkan hasil penelitian, didapatkan bahwa sebesar 42,9\% siswa kadang-kadang merasa tertantang untuk mengetahui lebih jauh materi yang diberikan guru selama masa pandemi, artinya siswa selalu membutuhkan motivasi untuk belajar, tugas guru selalu memberikan motivasi kepada siswa meskipun masa pandemi covid-19.

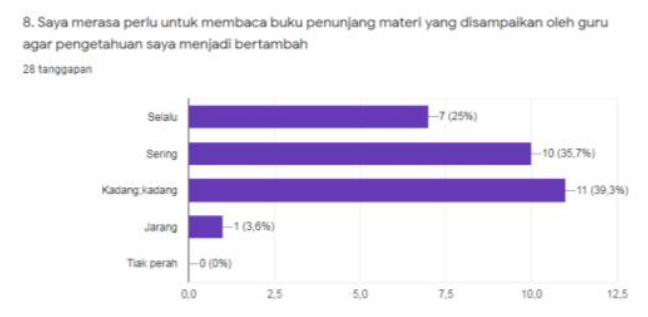

Tabel 4.8

Melalui pertanyaan dari angket : Saya merasa perlu untuk membaca buku penunjang materi yang disampaikan agar pengetahuan saya menjadi bertambah, didapatkan hasil respon sejumlah 28 siswa,seperti berikut :

Sebesar $25 \%$ siswa selalu merasa perlu untuk membaca buku penunjang,sebesar $35,7 \%$ siswa sering merasa perlu untuk membaca buku penunjang, sebesar 39,3\% siswa kadangkadang merasa perlu untuk membaca buku penunjang materi yang disampaikan agar pengetahuan saya menjadi bertambah,sebesar $3,6 \%$ siswa jarang merasa perlu untuk membaca buku penunjang materi, sertasebesar $0 \%$ siswa tidak pernah merasa perlu untuk membaca buku penunjang materi yang disampaikan agar pengetahuan saya menjadi bertambah.

Berdasarkan hasil penelitian, bahwa pada umumnya siswa kadang-kadang merasa perlu untuk membaca buku penunjang materi, agar pengetahuan siswa menjadi bertambah.

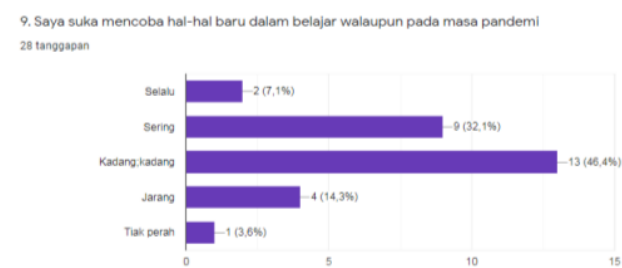

Tabel 4.9

Melalui pertanyaan dari angket : Saya suka mencoba hal-hal baru dalam belajar, walaupun pada masa pandemi, didapatkan data hasil respons sejumlah 28 siswa seperti berikut :

Sebesar $7,1 \%$ siswa selalu mencoba hal-hal baru dalam belajar, walaupun pada masa pandemi, sebesar $32,1 \%$ siswa sering mencoba hal-hal baru dalam belajar, walaupun pada masa pandemi, sebesar 46,4\% siswa kadang-kadang suka mencoba hal-hal baru dalam belajar, walaupun pada masa pandemi,sebesar 14,3\% siswa jarang mencoba hal-hal baru dalam belajar, walaupun pada masa pandemi, sertasebesar $3,6 \%$ siswa tidak 
pernah mencoba hal-hal baru dalam belajar, walaupun pada masa pandemi.

Berdasarkan hasil penelitian, didapatkan hasil bahwa siswa kadangkadangmencoba hal-hal baru dalambelajar, walaupun pada masa pandemi.

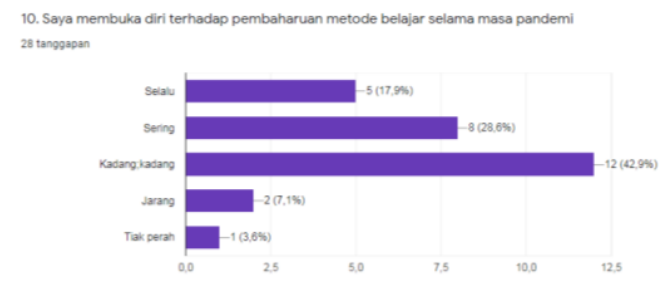

Tabel 4.10

Melalu pertanyaan angket : Saya membuka diri terhadap pembaharuan metode belajar selama masa pandemi, didapatkan hasil respon siswa sebanyak 28 siswa seperti berikut :

Sebesar $17,9 \%$ siswa selalu membuka diri terhadap pembaharuan metode belajar masa pandemi, sebesar 28,6\% siswa sering membuka diri terhadap pembaharuan metode belajar di masa pandemi, sebesar 42,9\% siswa kadang-kadang membuka diri terhadap pembaharuan metode belajar, sebesar $7,1 \%$ siswa jarang membuka diri terhadap pembaharuan metode belajar di masa pandemi, sebesar $3,6 \%$ siswa tidak pernah membuka diri terhadap pembaharuan metode belajar di masa pandemi.

Berdasarkan hasil penelitian didapatkan bahwa siswa kadang-kadang membuka diri terhadap pembaharuan metode pembelajaran selama masa pandemi covid-19.

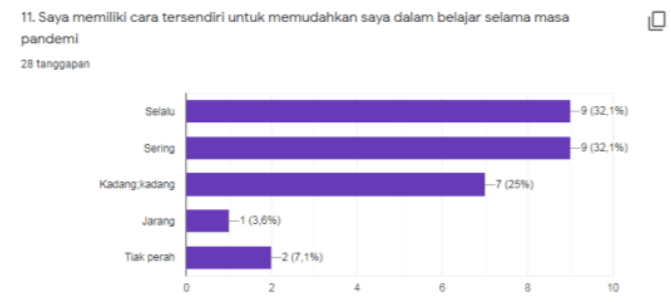

Tabel 4.11

Melalui pertanyaan : Saya memiliki cara tersendiri untuk memudahkan saya dalam belajar selama masa pandemi, didapatkan hasil respons dari 28 siswa seperti berikut :

Sebesar $32,1 \%$ siswa selalu memiliki cara tersendiri untuk memudahkan dalam belajar, sebesar $32,2 \%$ siswa sering memiliki cara tersendiri untuk memudahkan dalam belajar, sebesar 25\% siswa kadangkadang memiliki cara tersendiri untuk memudahkan dalam belajar, sebesar 3,6\% siswa jarang memiliki cara tersendiri untuk memudahkan dalam belajar dan sebesar $7,1 \%$ siswa tidak pernah memiliki cara tersendiri untuk memudahkan dalam belajar

Berdasarkan hasil penelitian dapat disimpulkan bahwa, siswa sering memiliki cara tersendiri untuk memudahkan dalam belajar selama masa pandemi, artinya siswa sudah memiliki cara tersendiri untuk memudahkan belajar selama masa pandemi covid-19.

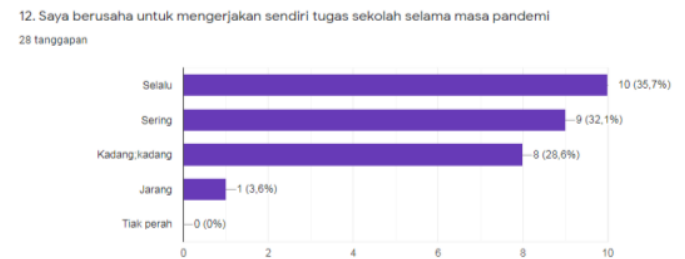

Tabel 4.12

Melalui pertanyaan dalam angket : Saya berusaha untuk mengerjakan sendiri tugas sekolah selama masa pandemi, didapatkan hasil penelitian dari sejumlah 28 siswa, seperti berikut :

Sebesar $35,7 \%$ siswa selalu berusaha untuk mengerjakan sendiri tugas sekolah di rumah, sebesar $32,1 \%$ siswa sering berusaha untuk mengerjakan sendiri tugas sekolah di rumah, sebesar $28,6 \%$ siswa kadang-kadang berusaha untuk mengerjakan sendiri tugas sekolah, sebesar $3,6 \%$ siswa jarang berusaha untuk mengerjakan sendiri tugas sekolah di rumah dan sebesar $0 \%$ siswa tidak pernah berusaha untuk mengerjakan sendiri tugas sekolah di rumah

Berdasarkan hasil penelitian dapat disimpulkan bahwa peserta didik/siswa selalu berusaha untuk mengerjakan sendiri tugas-tugas yang diberikan oleh guru selama masa pandemi,serta tidak ada siswa 
yang tidak pernah berusaha untuk mengerjakan sendiri tugas sekolah selama di rumah pada masa pandemi.

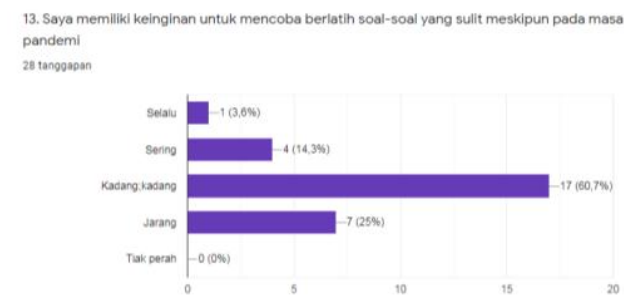

Tabel 4.13

Melalui pertanyaan dari angket : Saya memiliki keinginan untuk mencoba berlatih soal-soal yang sulit,meskipun pada masa pandemi, didapatkan hasil respon dari 28 siswa seperti berikut :

Sebesar 3,6\% siswa selalu memiliki keinginan untuk erlatih soal-soal yang sulit, sebesar $14,3 \%$ siswa sering memiliki keinginan untuk berlatih soal-soal yang sulit, sebesar 60,7\% siswa kadang-kadang memiliki keinginan untuk berlatih soal-soal yang sulit, sebesar 25\% siswa jarang memiliki keinginan untuk berlatih soal-soal yang sulit dan sebesar 0\% siswa tidak pernah memiliki keinginan untuk berlatih soal-soal yang sulit

Berdasarkan hasil penelitian dapat disimpulkan bahwa, pada umumnya siswa kadang-kadang memiliki keinginan kuat untuk mencoba berlatih mengerjakan soalsoal yang sulit, meskipun sedang masa pandemi, dan ditemukan tidak ada siswa yang tidak memiliki keinginan untuk mencoba berlatih soal-soal yang sulit, walaupun pada masa pandemi covid-19.

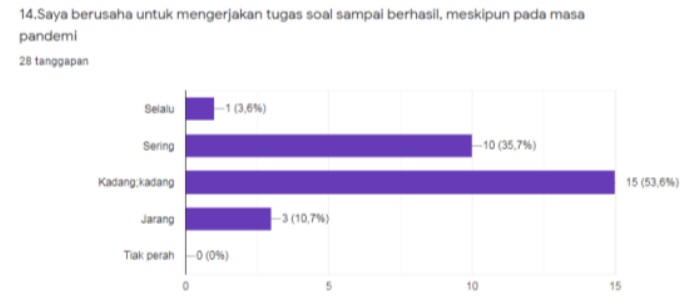

Tabel 4.14

Melalui pertanyaan dari angket : Saya berusaha untuk mengerjakan tugas sampai berhasil, meskipun pada masa pandemi, didapatkan data hasil respon dari 28 siswa seperti berikut :

Sebesar 3,6\% siswa selalu berusaha untuk mengerjakan tugas sampai berhasil, sebesar $35,7 \%$ siswa sering berusaha untuk mengerjakan tugas sampai berhasil, sebesar 53,6\% siswa kadang-kadang berusaha untuk mengerjakan tugas-tugas sampai berhasil, sebesar $10,7 \%$ siswa jarang berusaha untuk mengerjakan tugas-tugas sampai berhasil, sebesar 0\% siswa tidak pernah berusaha untuk mengerjakan tugastugas sampai berhasi.l

Berdasarkan hasil penelitian dapat disimpulkan bahwa, pada umumnya siswa kadang-kadangberusaha untuk mengerjakan tugas-tugas sampai berhasil, walaupun masa pandemi, serta tidak ada siswa yang tidak berusaha untuk mengerjakan tugas-tugas sampai berhasil, serta tidak ada siswa yang tidak mau berusaha untuk mengerjakan tugas-tugas sekolah sampai berhasil.

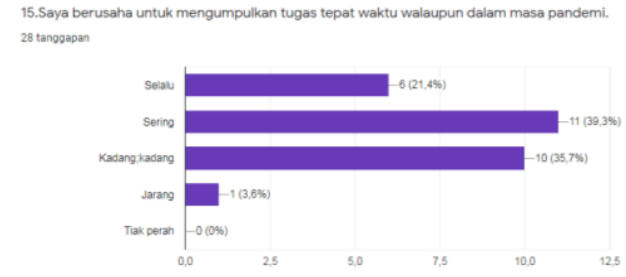

Tabel 4.15

Melalui pertanyaan dalam angket : Saya berusaha untuk mengumpulkan tugas tepat waktu, walaupun dalam masa pandemi, didapatkan hasil respon dari 28 siswa, seperti berikut :

Sebesar $21,4 \%$ siswa selalu berusaha untuk mengumpulkan tugas tepat waktu, sebesar 39,3\% siswa sering berusaha untuk mengumpulkan tugas tepat waktu, sebesar $35,7 \%$ siswa kadang-kadang berusaha untuk mengumpulkan tugas tepat waktu, sebesar 3,6\% siswa jarang berusaha untuk mengumpulkan tugas tepat waktu dan sebesar $0 \%$ siswa tidak pernah berusaha mengumpulkan tugas tepat waktu.

Berdasarkan hasil penelitian, dapat disimpulkan bahwa pada umumnya siswa sering berusaha untuk mengumpulkan 
tugas secara tepat waktu, walaupun pada masa pandemi, serta tidak ada siswa yang tidak pernah berusaha untuk mengumpulkan tugas secara tepat waktu, walaupun pada masa pandemi.

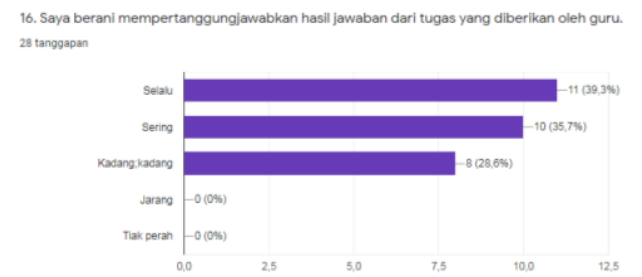

Tabel 4.16

Melalui pertanyaan dalam angket : Saya berani mempertanggungjawabkan hasil jawaban dari tugas yang diberikan oleh guru selama masa pandemi, didapatkan data dari respon 28 siswa seperti berikut :

Sebesar 39,3\% siswa selalu berani mempertanggungjawabkan hasil jawaban dari tugas yang diberikan oleh guru, sebesar $35,7 \%$ siswa sering berani mempertanggungjawabkan hasil jawaban dari tugas-tugas, sebesar $28,6 \%$ siswa kadang-kadang berani mempertanggungjawabkan hasil jawaban dari tugas-tugas yang diberikan oleh guru selama masa pandemi, sebesar $0 \%$ siswa jarang berani mempertanggungjawabkan hasil jawaban dari tugas-tugas dan sebesar $0 \%$ siswa tidak pernah berani mempertanggungjawabkan hasil jawaban dari tugas-tugas.

Berdasarkan hasilpenelitian, dapat disimpulkan bahwa sebanyak 39,3\% siswa selalu berani mempertanggungjawabkan hasil jawaban dari tugas-tugas yang diberikan oleh guru selama masa pandemi, artinya siswa memiliki rasa tanggungjawab yang tinggi untuk melaksanakan tugastugas yang diberikan oleh guru, meskipun dalam masa pandemi.

Artinya semua siswa berani mempertanggungjwabkan hasil jawaban dari tugas-tugas yang diberikan oleh guru, meskipun dalam masa pandemi.

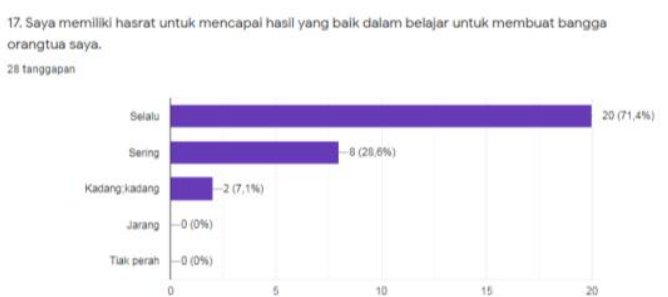

Tabel 4.17

Melalui pertanyaan dalam angket : Saya memiliki hasrat untuk mencapai hasil yang baik dalam belajar untuk membuat bangga orang tua saya, didapatkan hasil respon dari 28 siswa seperti berikut

Sebesar $71,4 \%$ siswa selalu memiliki hasrat untuk mencapai hasil yang baik dalam belajar, sebesar $28,4 \%$ siswa sering memiliki hasrat untuk mencapai hasil yang baik dalam belajar, sebesar $7,1 \%$ siswa kadang-kadang memiliki hasrat untuk mencapai hasil yang baik dalam belajar, sebesar 0\% siswa jarang memiliki hasrat untuk mencapai hasil yang baik dalam belajar dan sebesar $0 \%$ siswa tidak pernah memiliki hasrat untuk mencapai hasil yng baik dalam belajar.

Berdasarkan hasil penelitian, dapat disimpulkan bahwa, pada umumnya memiliki hasrat untuk mencapai hasil yang baik dalam belajar, meskipun pada masa pandemi, dan tidak ada siswa yang tidak memiliki hasrat untuk mencapai hasil belajar yang baik .

Artinya hampir semua siswa memiliki motivasi yang tinggi untuk mencapai hasil belajar yng baik, yang bisa menjadi kebanggaan orang tua.

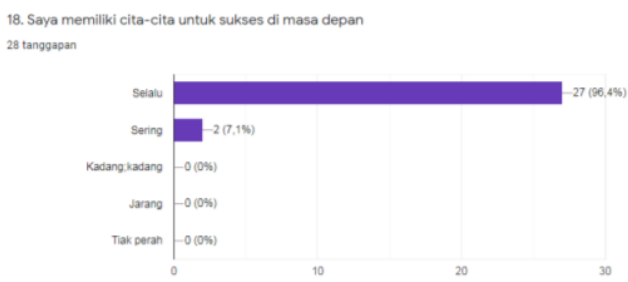

Tabel 4.18

Melalui pertanyaan angket :Saya memiliki cita-cita untuk sukses di masa depan, didapatkan data dari 28 respon siswa, seperti berikut : 
Sebesar $96,4 \%$ siswa selalu memiliki cita-cita untuk sukses di masa depan, sebesar 3,6\% siswa sering memliki cita-cita untuk sukses di masa depan, sebesar 0\% siswa kadang-kadang memiliki cita-cita untuk sukses di masa depan, sebesar 0\% siswa jarang memiliki cita-cita untuk sukses di masa depan dan sebesar $0 \%$ siswa tidak pernah memiliki cita-cita untuk sukses di masa depan.

Berdasrkan hasil penelitian, dapat disimpulkan bahwa sebesar 96,4\% siswa memiliki cita-cita untuk sukses di masa depan, serta tidak ada siswa yang menginginkan tidak sukses di masa depan kehidupannya.

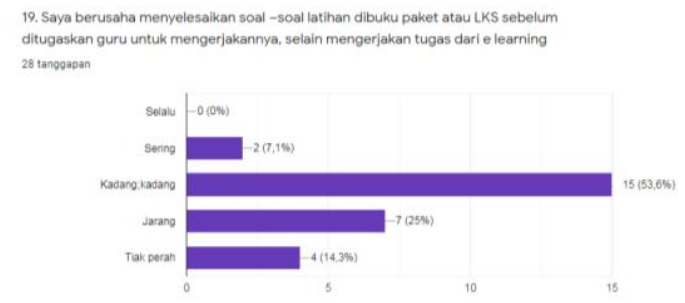

Tabel 4.19

Melalui pertanyaan dalam angket : Saya berusaha menyelesaikan soal-soal latihan di buku paket atau lks sebelum ditugaskan guru untuk mengerjakannya, selain mengerjakan tugas dari e-learning, didapatkan hasil respon dari 28 siswa seperti berikut :

Sebesar 0\% siswa selalu berusaha untuk mengerjakan soal-soal latihan sebelum ditugaskan guru, sebesar 7,1\% siswa sering berusaha untuk mengerjakan soal-soal latihan sebelum ditugaskan guru, sebesar $53,6 \%$ siswa kadang-kadang berusaha untuk mengerjakan soal-soal latihan sebelum ditugaskan oleh guru, sebesar 25\% siswa jarang berusaha untuk mengerjakan soal-soal latihan sebelum ditugaskan guru dan sebesar $14,3 \%$ siswa tidak pernah berusaha mengerjakan soalsoal latihan sebelum ditugaskan guru

Berdasarkan hasil penelitian, dapat disimpulkan bahwa, sebesar $53,6 \%$ siswa kadang-kadang berusaha mengerjakan soal-soal latihan sebelum ditugaskan oleh guru, selain mengerjakan tugas dari e- learning, artinya siswa baru mengerjakan tugas-tugas setelah ada instruksi dari guru.

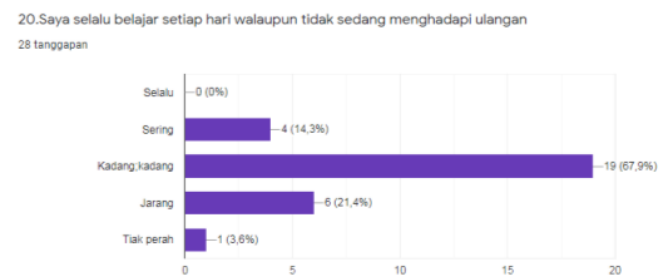

Tabel 4.20

Melalui pertanyaan dalam angket : Saya selalu belajar setiap hari walaupun tidak sedang menghadapi ulangan, didapatkan data hasil respon dari 28 siswa, seperti berikut :

Sebesar 0\% siswa selalu belajar setiap hari, walaupun tidak sedang menghadapi ulangan, sebesar $14,3 \%$ siswa sering belajar setiap hari walaupun tidak sedang menghadapi ulangan, sebesar $67,9 \%$ siswa kadang-kadang belajar setiap hari walaupun tidak sedang ulangan, sebesar $21,4 \%$ siswa jarang belajar setiap hari walaupun tidak sedang menghadapi ulangan, dan sebesar 3,6\% siswa tidak pernah belajar setiap hari walaupun tidak sedang menghadapi ulangan.

Berdasarkan hasil penelitian dapat disimpulkan bahwa, siswa kadang-kadang belajar setiap hari walaupun tidak sedang menghadapi ulangan, artinya siswa pada umumnya belajar ketika menghadapi masa ulangan/ujian.

\section{F. Kesimpulan}

Berdasarkan hasil penelitian melalui pertanyaan angket yang diberikan melalui G-Formulir, pada kelas XII IPA2, selama masa pandemi dapat diambil kesimpulan sebagai berikut :

1. Kemandirian belajar siswa kelas XII IPA2 selama masa pandemi dalam pembelajaran Biologi, perlu dimotivasi ,berdasarkan hasil angket didapatkan jawaban bahwa siswa kadang-kadang merasa tertantang untuk mengetahui lebih jauh materi yang diberikan guru, merasa perlu untuk membaca buku penunjang materi, agar menambah 
wawasan belajar siswa, mencoba halhal baru dalam belajar, membuka diri terhadap pembaharuan metode pembelajaran, mempunyai keinginan kuat untuk berlatih soal-soal yang sulit, berusaha mengerjakan tugas sampai berhasil, berusaha untuk mengerjakan tugas/soal sebelum ditugaskan oleh guru, belajar setiap hari walaupun tidak sedang menghadapi ulangan .

2. Untuk motivasi intrinsik siswa, sudah cukup baik, dari hasil angket didapatkan bahwa siswa selalu berusaha untuk mengerjakan sendiri tugas-tugas yang diberikan oleh guru, siswa memiliki cara tersendiri untuk memudahkan dalam belajar, siswa berusaha mengumpulkan tugas secara tepat waktu, siswa selalu berani mempertanggung jawabkan hasil jawaban dari tugas yang diberikan guru, siswa memiliki hasrat untuk mencapai hasil belajar yang baik, siswa memiliki cita-cita untuk sukses di masa depan.

3. Faktor dari orang tua dalam mendorong anak-anak nya untuk belajar mandiri selama masa pandemi, didapatkan hasil respon, cukup baik, terbukti dengan adanya orang tua menyediakan sarana belajar siswa selama masa pandemi, orang tua kadang-kadang memantau belajar siswa, memahami permasalahan belajar siswa, membantu memecahkan masalah belajar anaknya, walaupun ada orang tua yang tidak pernah menjalin komunikasi dengan pihak sekolah selama masa pandemi.

\section{DAFTAR PUSTAKA}

Ali, Muhammad,2009, Pendidikan untuk pembangunan, Jakarta, Imtima.

Ali M, Aisyyah, Pendidikan karakter, konsep dan implementasinya, Jakarta, Kencana, 2013
Arikunto, S,2006, Prosedur penelitian suatu pendekatan praktis, Jakarta, Rinekacipta

Asrori, M,2010, Psikologi remaja perkembangan peserta didik, Jakarta, Bumi aksara

Basri, Hasan, 2000, Kiat sukses melalui kecerdasan emosional dan kemandirian belajar, Razibook

Mujiman, Haris, 2006, Manajemen pelatihan berbasis belajar mandiri, Yogyakarta, Pustaka belajar

Nurhayati, Eti, 2011, Psikologi Pendidikan Inovatif, Yogyakarta, Pustaka belajar

Nurwahyuni, Esa, Baharudin, 2007, Teori Belajar dan Pembelajaran, Yogyakarta, Arruzz Media

Rosnida, 2007, Kemandirian dalam perilaku, Jakarta, Bumi aksara

Sukarno, Anton, 1999, Ciri kemandirian belajar, Jakarta, Kencana Prenada Media

Thursan, Hakim, 2006, mengatasi rasa tidak percaya diri, Jakarta, Puspa swara

Utomo, Jacob, 1990, Kemandirian belajar siswa perlu ditingkatkan, Jakarta, Bumi aksara. 